\title{
Malar rash in classical homocystinuria
}

\author{
Arushi Gahlot Saini, Hansashree Padmanabha, Savita Attri, Pratibha Singhi
}

Department of Pediatrics, Postgraduate Institute of Medical Education and Research, Chandigarh, India

\section{Correspondence to} Professor Pratibha Singhi, doctorpratibhasinghi@gmail. com

Accepted 19 April 2017

\section{(a) CrossMark}

To cite: Saini $A G$, Padmanabha $\mathrm{H}$, Attri S, et al. BMJ Case Rep Published Online First: [please include Day Month Year]. doi:10.1136/bcr-2017220296

\section{DESCRIPTION}

An 8-year-old girl with intellectual disability and severe myopia presented with subacute bilateral painless loss of vision. Anthropometric examination showed a weight of $26 \mathrm{~kg}(-0.1 \mathrm{Z}$ score), height of $122.5 \mathrm{~cm}$ (between -1 and $-2 \mathrm{Z}$ score), arm span of $129 \mathrm{~cm}(6.5 \mathrm{~cm}$ longer than the height $)$ and head circumference of $51 \mathrm{~cm}$ (between -1 and $-2 \mathrm{Z}$ score). Physical examination showed thin, hypopigmented hair with malar rash (figure 1A), acral hyperpigmentation, bilateral inferonasal subluxation of lens and bilateral optic atrophy. Other marfanoid features such as arachnodactyly, high-arched palate, joint hyperlaxity and cardiac anomalies were absent. A clinical diagnosis of classical homocystinuria was considered. Investigations showed elevated plasma homocysteine of $209 \mu \mathrm{mol} / \mathrm{L}$ (range $5-15 \mu \mathrm{mol} / \mathrm{L}$ ), urine homocystine of $76 \mathrm{mmol} / \mathrm{mol}$ creatinine (range $0-4 \mathrm{mmol} /$ mol creatinine), serum vitamin $\mathrm{B}_{12}$ of $445 \mathrm{pg} / \mathrm{mL}$ (211-911 pg/mL), normal methionine of $51 \mu \mathrm{mol} / \mathrm{L}$ $(0-75 \mu \mathrm{mol} / \mathrm{L})$ and a normal carnitine profile, which confirmed our clinical diagnosis. MRI of the brain showed normal parenchyma with bilateral dislocation of lens (figure 1B). She was started on oral pyridoxine, folate and betaine. Currently, after 3 months of treatment, there is improvement in vision and cognitive functions. However, the malar rash is still persistent with only mild reduction in erythema.

Characteristic features of classic homocystinuria caused by cystathionine-beta-synthase deficiency includes developmental delay or intellectual

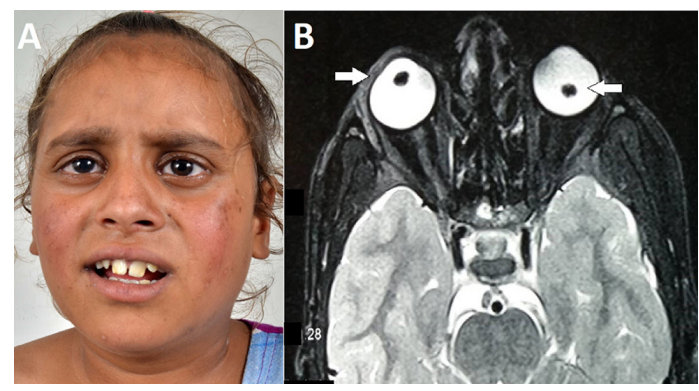

Figure 1 (A) Facial picture of the index patient showing bilateral malar flush noticed since the age of 5 years and thin, hypopigmented and lustreless hair. (B) MRI of brain showing bilateral lens dislocation in the eyes. The rest of the brain parenchyma (not shown) was normal. disability, myopia commonly evident after 1 year of age and ectopia lentis usually by 8 years of age, excessive height and limb length, skeletal abnormalities and vascular thromboembolism. ${ }^{1}$ Less commonly, a peculiar 'malar' rash on the cheeks (malar flush) may be seen and may lead to an incorrect diagnosis of systemic lupus in adolescent girls. It can be easily seen after vigorous exercise or after exposure to the cold. The probable biochemical mechanism is inhibition of tyrosinase enzyme by interaction of homocysteine with copper at the active site of tyrosinase ${ }^{2}$ and this leads to reduced melanin and manifests as malar rash and fragile hair. Hence, malar flush in a child with lens dislocation and intellectual impairment should lead to a suspicion of classical homocystinuria.

\section{Learning points}

- Malar rash is an unusual cutaneous manifestation of classic homocystinuria.

- Probable mechanism would be attributed to inhibition of tyrosinase enzyme by interaction of homocysteine with copper at active site of tyrosinase.

- Malar rash with intellectual disability and lens dislocation would point towards a clinical diagnosis of homocystinuria.

Contributors AGS: Patient management, draft of manuscript and review of literature. HP: Patient management and review of manuscript. SA: Analysis and interpretation of biochemical data and manuscript editing. PS: Clinician-in-charge and critical review of manuscript for intellectual content and final approval of the version to be published.

Competing interests None declared.

Patient consent Consent obtained from guardian.

Provenance and peer review Not commissioned; externally peer reviewed.

(c) BMJ Publishing Group Ltd (unless otherwise stated in the text of the article) 2017. All rights reserved. No commercial use is permitted unless otherwise expressly granted.

\section{REFERENCES}

1 Kruger WD, Wang L, Jhee KH, et al. Cystathionine beta-synthase deficiency in Georgia (USA): correlation of clinical and biochemical phenotype with genotype. Hum Mutat 2003;22:434-41.

2 Reish 0, Townsend D, Berry SA, et al. Tyrosinase inhibition due to interaction of homocyst(e)ine with copper: the mechanism for reversible hypopigmentation in homocystinuria due to cystathionine beta-synthase deficiency. Am J Hum Genet 1995;57:127-32. 
Copyright 2017 BMJ Publishing Group. All rights reserved. For permission to reuse any of this content visit http://group.bmj.com/group/rights-licensing/permissions.

BMJ Case Report Fellows may re-use this article for personal use and teaching without any further permission.

Become a Fellow of BMJ Case Reports today and you can:

- Submit as many cases as you like

- Enjoy fast sympathetic peer review and rapid publication of accepted articles

Access all the published articles

- Re-use any of the published material for personal use and teaching without further permission

For information on Institutional Fellowships contact consortiasales@bmjgroup.com

Visit casereports.bmj.com for more articles like this and to become a Fellow 